\title{
Functional integrity of the retrosplenial cortex is essential for rapid consolidation and recall of fear memory
}

\author{
Cynthia Katche, ${ }^{1}$ Guido Dorman, ${ }^{1}$ Leandro Slipczuk, ${ }^{2}$ Martín Cammarota, ${ }^{3}$ \\ and Jorge $\mathrm{H}$. Medina ${ }^{1,4,5}$ \\ ${ }^{1}$ Instituto de Biologia Celular y Neurociencias, Facultad de Medicina, UBA, Buenos Aires (1121 ABC), Argentina; ${ }^{2}$ Department of \\ Medicine, Einstein Medical Center, Philadelphia, Pennsylvania 19141, USA; ${ }^{3}$ Laboratório de Neurobiologia do Comportamento, \\ Instituto de Pesquisas Biomédicas, PUCRS, RS90610-000, Porto Alegre, Brasil; ${ }^{4}$ Departamento de Fisiologia, Facultad de Medicina, \\ UBA, Buenos Aires (1121 ABG), Argentina
}

\begin{abstract}
Memory storage is a temporally graded process involving different phases and different structures in the mammalian brain. Cortical plasticity is essential to store stable memories, but little is known regarding its involvement in memory processing. Here we show that fear memory consolidation requires early post-training macromolecular synthesis in the anterior part of the retrosplenial cortex (aRSC), and that reversible pharmacological inactivation of this cortical region impairs recall of recent as well as of remote memories. These results challenge the generally accepted idea that neocortical areas are slow encoding systems that participate in the retrieval of remote memories only.
\end{abstract}

[Supplemental material is available for this article.]

\begin{abstract}
A dominant idea that emerged in the last two decades is that memory consolidation comprises two phases. The initial one, called cellular or synaptic consolidation, is fast, lasting from several hours to a couple of days, and depends on de novo protein and mRNA synthesis required for functional and structural changes in brain regions engaged in the acquisition and early processing of new information, such as the hippocampus and related noncortical structures (Dudai 2002; Dudai and Eisenberg 2004; Morris 2006). The second phase is slower, and would entail the participation of neocortical regions and their interactions with medial temporal lobe structures reorganizing the recently learned material (Squire 1992). It is called systems-level consolidation and seems to begin late after acquisition and last from several days to weeks to months in most learning tasks studied so far (Frankland and Bontempi 2005). However, when recently encoded information interacts with an already stored associative schema, systems-level consolidation may well be very rapid (Tse et al. 2007, 2011). Consistent with the standard model of memory consolidation, it has been shown that, while the hippocampus is mainly involved in consolidating and recalling recent episodic-like memories, some cortical regions, including prelimbic, orbitofrontal, and anterior cingulate areas, are involved preferentially with remote, well-consolidated memory traces (Frankland et al. 2004; Maviel et al. 2004; Shan et al. 2008; Lesburgueres et al. 2011; Tse et al. 2011).

The retrosplenial cortex (RSC) comprises the entire posterior cingulate cortex in rodents (Vogt and Peters 1981) and is one of the largest cortical areas in the rat. Situated at the crossroads between the hippocampal formation and many neocortical areas, it has attracted much attention especially for its involvement in cognition (Vann et al. 2009). Although RSC inactivation produces memory impairments similar to those caused by hippocampal
\end{abstract}

\footnotetext{
${ }^{5}$ Corresponding author

E-mail jmedina@fmed.uba.ar

Article is online at http://www.learnmem.org/cgi/doi/10.1101//m.030080.112.
}

lesions (Cooper and Mizumori 2001; Vann and Aggleton 2004), and it has been shown that RSC is activated during retrieval of contextual information and autobiographical memory (Valenstein et al. 1987, Daselaar et al. 2006), the precise function of this area is poorly understood (Ranganath and Ritchey 2012). To study the precise role of RSC in fear memory processing we used a single-trial, step-down version of the inhibitory avoidance (IA) learning paradigm in rats (see Supplemental Methods for details). Training in this paradigm induces a fear-motivated, hippocampus-dependent, long-lasting memory and permits the uncontaminated analysis of the different stages of memory processing initiated by a single training experience (Izquierdo and Medina 1997; Taubenfeld et al. 1999; Bekinschtein et al. 2007).

A definite property of cellular consolidation is its sensitivity to protein synthesis inhibitors (McGaugh 2000; Kandel 2001; Alberini 2008). To analyze whether protein synthesis is necessary in RSC for fear-memory consolidation, rats received bilateral microinfusions of the protein synthesis inhibitor emetine (50 $\mu \mathrm{g} / \mu \mathrm{L}$ ) (Lima et al. 2009) in the anterior part of the RSC (aRSC; Fig. 1) 15 min before or $9 \mathrm{~h}$ after IA training, and were tested for long-term memory (LTM) retention $2 \mathrm{~d}$ later. Emetine infusion impaired IA LTM when given before the training session, but had no effect on retention when administered $9 \mathrm{~h}$ thereafter $(P<0.001, t=4.677, n=10$ per group, Student's $t$-test [Fig. $2 \mathrm{~A}$, white bars]). The amnesic effect of the pretraining administration of emetine was also observed in a different group of IA trained rats tested 7 d post-training $(P<0.05, t=2.307, n=10$ per group, Student's $t$-test [Fig. 2A, gray bars]). Emetine did not affect IA short-term memory tested $3 \mathrm{~h}$ post-training (Izquierdo and Medina 1997) when given in aRSC 15 min before training $(P>$ $0.05, t=0.4519$, Student's $t$-test [Fig. 2B]). The amnesic effect of emetine on IA LTM was replicated infusing anisomycin, a different protein synthesis inhibitor $(80 \mu \mathrm{g} / \mu \mathrm{L}$ ) (Bourtchouladze et al. 1998) ( $2 \mathrm{~d}, P<0.01, t=3.665$ [Fig. 2C, white bars]; $7 \mathrm{~d}$, 


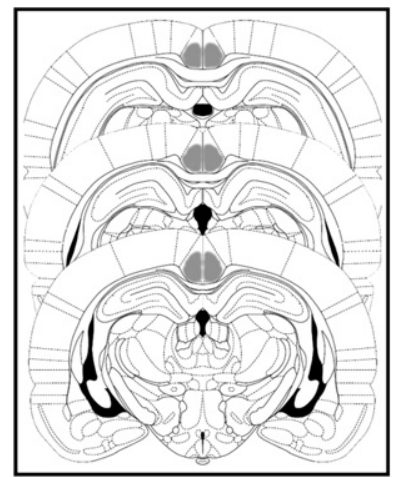

Figure 1. Site of drug infusion. Schematic representations of coronal brain sections at three rostrocaudal planes $(-3.80,-4.30$, and -4.80 from bregma), showing the extension of the area (gray) reached by the infusions in the aRSC (Paxinos and Watson 1997).
It is currently accepted that the hippocampus participates in the retrieval of recent, but not of remote memories. The cortex, instead, would be expressly involved in the retrieval of old, but not of new memories (Frankland and Bontempi 2005). To analyze whether this is the case for the aRSC, we trained rats in IA and, $15 \mathrm{~min}$ before a retention test session carried out $1 \mathrm{~d}, 7 \mathrm{~d}$, or 21 $\mathrm{d}$ later, we inactivated the aRSC by means of muscimol microinfusions (Martin 1991). As can be seen in Figure 3A, muscimol (0.1 $\mu \mathrm{g} / \mu \mathrm{L})$ abolished retrieval of recent as well as of remote memories (test at $24 \mathrm{~h},<0.01, t=3.643$; test at $7 \mathrm{~d}, P<0.5, t=2.101$; test at $21 \mathrm{~d}, P<0.01, t=4.285 ; n=8$ per group, Student's $t$-test [Fig. $3 \mathrm{~A}$, gray bars]). This effect was reversible, since the impairment was not seen when the animals were retested $1 \mathrm{~d}$ later (Fig. 2B).

The results presented above indicate that aRSC is critically involved in processing recently acquired information about fearful experiences, and that this cortex is required for expression of both recent and remote fear memories. On the other hand, a recent study of fear conditioning in mice showed that blocking
$P<0.05, \quad t=2.612, n=8$ per group, Student's $t$-test [Fig. 2C, gray bars]). Gene expression is also a requirement for cellular consolidation (McGaugh 2000; Igaz et al. 2002; Duvarci et al. 2008). Consequently, we infused the specific inhibitor of RNA polymerase II $\alpha$-amanitin in the aRSC at a dose known to block memory formation in the hippocampus (Igaz et al. 2002). In Figure 2D we show that $\alpha$-amanitin infusion $(0.5$ $\mu \mathrm{g} / \mathrm{side}) 15 \mathrm{~min}$ before IA training impaired memory retention when tested 2 $\mathrm{d}$ after training $(P<0.05, t=2.743, n=$ 8 per group, Student's t-test [Fig. 2D, white bars]). A different group of rats infused with $\alpha$-amanitin $15 \mathrm{~min}$ before IA training also showed impaired LTM when tested $7 \mathrm{~d}$ later $(P<0.05, t=$ $2.474, n=8$ per group, Student's $t$-test [Fig. 2D, gray bars]). Intra-aRSC infusion of $\alpha$-amanitin $6 \mathrm{~h}$ after IA training had no effect on memory retention $2 \mathrm{~d}$ or $7 \mathrm{~d}$ after training $(2 \mathrm{~d}, P>0.05, t=0.7730$, $n=10$ per group [Fig. 2D, white bars]; 7 $\mathrm{d}, P>0.05, t=0.8327, n=10$ per group, Student's $t$-test [Fig. 2D, gray bars]). In addition, $\alpha$-amanitin did not affect IA shortterm memory tested at $3 \mathrm{~h}$ when given in aRSC $15 \mathrm{~min}$ before training $(P>0.05$, $t=0.2107$, Student's $t$-test [Fig. 2E]). These findings indicate that gene expression and protein synthesis are needed in aRSC at the moment of training, but not later, for normal retention, suggesting that cellular consolidation of IA LTM takes place in aRSC and that this structure may, indeed, encode fearful experiences at least as fast as the hippocampus. The fact that IA STM was not affected by pretraining intra-aRSC infusion emetine or $\alpha$-amanitin indicates that the amnesia caused by these compounds was not due to impaired acquisition or to a protracted deleterious effect on retrieval.
A

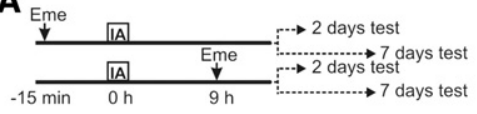

B
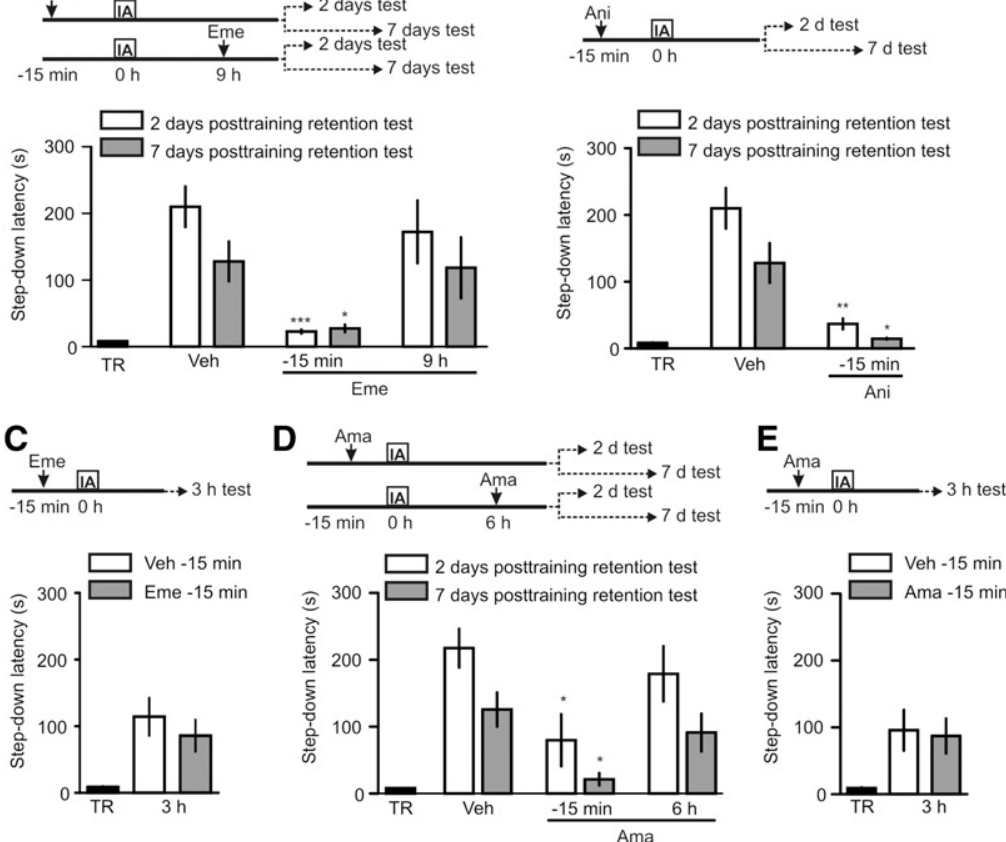

Figure 2. aRSC is required for memory formation. (A) Protein synthesis is required for LTM formation. Animals were infused into aRSC with vehicle (Veh) or emetine (Eme, $50 \mu \mathrm{g} / 1 \mu \mathrm{L} /$ side) $15 \mathrm{~min}$ before training or $9 \mathrm{~h}$ after training. Data are expressed as mean $\pm \mathrm{SEM}$ of training (TR, black bar) or test session step-down latency $2 \mathrm{~d}$ (white bars) or $7 \mathrm{~d}$ (gray bars) after IA training. $\left({ }^{* * *}\right) P<0.001,\left(^{*}\right) P<0.05$ vs. Veh; two-tailed Student's $t$-test, $n=10-12$ per group. $(B)$ Early protein synthesis is required for LTM formation. Animals were infused into aRSC with vehicle (Veh) or anisomycin (Ani, $80 \mu \mathrm{g} / 1 \mu \mathrm{L} / \mathrm{side}$ ) 15 min before training. Data are expressed as mean \pm SEM of training (TR, black bar) or test session step-down latency $2 \mathrm{~d}$ (white bars) or $7 \mathrm{~d}$ (gray bars) after IA training. $\left({ }^{*}\right) P<0.05,\left({ }^{* *}\right) P<0.01$ vs. Veh; two-tailed Student's $t$-test, $n=10-14$ per group. (C) Protein synthesis inhibition around training does not affect memory acquisition in the aRSC. Animals were infused into aRSC with vehicle (Veh, white bar) or emetine (Eme, $50 \mu \mathrm{g} / 1 \mu \mathrm{L} /$ side, gray bar) 15 min before training and were tested $3 \mathrm{~h}$ after IA training. Data are expressed as mean \pm SEM of training (TR, black bar) or test session step-down latency $3 \mathrm{~h}$ after IA training. $P>0.05$ vs. Veh; two-tailed Student's $t$-test, $n=10-12$ per group. $(D)$ mRNA synthesis is required for LTM formation in aRSC. Animals were infused into aRSC with vehicle (Veh) or $\alpha$-amanitin (Ama, $0.5 \mu \mathrm{M} / 1 \mu \mathrm{L} /$ side), $-15 \mathrm{~min}$ or $6 \mathrm{~h}$ after IA training. Data are expressed as mean \pm SEM of training (TR, black bar) or test session step-down latency $2 \mathrm{~d}$ (white bars) or $7 \mathrm{~d}$ (gray bars) after IA training. $(*) P<0.05$ vs. Veh; two-tailed Student's $t$-test, $n=10-12$ per group. $(E)$ mRNA synthesis inhibition around training does not affect memory acquisition in the aRSC. Animals were infused into aRSC with vehicle (Veh, white bar) or $\alpha$-amanitin (Ama, $0.5 \mu \mathrm{M} / 1 \mu \mathrm{L}$ ) side, gray bar) $15 \mathrm{~min}$ before training and were tested $3 \mathrm{~h}$ after IA training. Data are expressed as mean \pm SEM of training (TR, black bar) or test session step-down latency $3 \mathrm{~h}$ after IA training. $P>$ 0.05 vs. Veh; two-tailed Student's $t$-test, $n=10-12$ per group. 
A
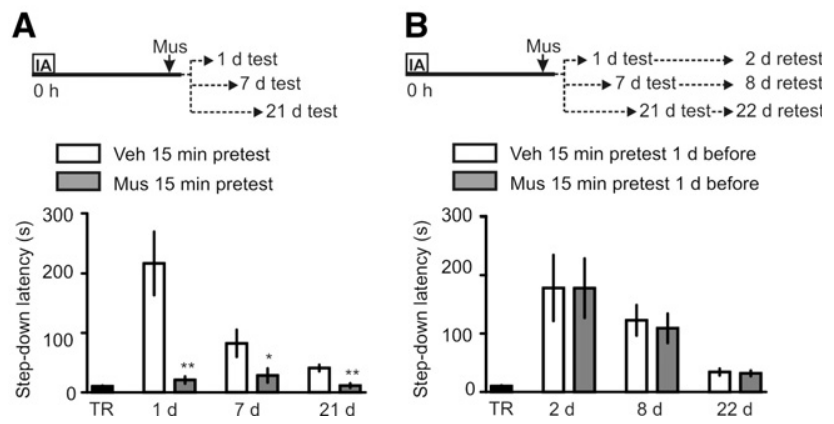

Figure 3. aRSC activation is required for recall of recent and remote memories. $(A)$ Pretest inactivation of aRSC impairs memory recall. Animals were infused into aRSC with vehicle (Veh, white bars) or muscimol (Mus, $0.1 \mu \mathrm{g} / 1 \mu \mathrm{L} / \mathrm{side}$, gray bars) $15 \mathrm{~min}$ before retention test sessions at $1 \mathrm{~d}, 7 \mathrm{~d}$, or $21 \mathrm{~d}$ after training. Data are expressed as mean \pm SEM of training (TR, black bar) or test session step-down latency $1 \mathrm{~d}, 7 \mathrm{~d}$, or 21 $\mathrm{d}$ after IA training. ( $\left.{ }^{*}\right) P<0.05,\left(^{* *}\right) P<0.01$ vs. Veh; two-tailed Student's $t$-test, $n=8-12$ per group. (B) Pretest inactivation of aRSC impairment is reversible. Animals were infused into aRSC with vehicle (Veh, white bars) or muscimol (Mus, $0.1 \mu \mathrm{g} / 1 \mu \mathrm{L} /$ side, gray bars) $15 \mathrm{~min}$ before retention test sessions at $1 \mathrm{~d}, 7 \mathrm{~d}$, or $21 \mathrm{~d}$ after training and retested a day after. Data are expressed as mean \pm SEM of training (TR, black bar) or retest session step-down latency $2 \mathrm{~d}, 8 \mathrm{~d}$, or $22 \mathrm{~d}$ after IA training. $P>0.05 \mathrm{vs.} \mathrm{Veh;} \mathrm{two-}$ tailed Student's $t$-test, $n=8-12$ per group.

NMDA receptors prior to context conditioning did not affect learning (Corcoran et al. 2011). Probably, other neurotransmitter receptors are involved in initial steps of memory processing in the RSC.

Several lesion studies have involved RSC in memory (Sutherland et al. 1988; Vann and Aggleton 2002, 2004; Harker and Whishaw 2004; Keene and Bucci 2008a,b,c; Dumont et al. 2010; Haijima and Ichitani 2012; Robinson et al. 2012). However, this kind of intervention has several drawbacks (Izquierdo and Medina 1998), including a lack of discrimination between memory acquisition, memory formation, or memory expression. Memory is by no means a unitary event having several stages or phases. These facts strongly limit the interpretations and conclusions reached by irreversible lesion studies. In our work, we demonstrate for the first time the role of aRSC in memory formation without lesion experiments, using a classical approach in memory studies: a one-trial aversively motivated IA training and local delivery of protein synthesis and gene expression inhibitors around training.

The contribution of aRSC to consolidation and retrieval of a fear-motivated learning appears to be relevant enough that the hippocampus and the amygdala cannot sustain these processes by themselves (Izquierdo and Medina 1997; Alberini 2009) when aRSC is offline. This observation is pertinent inasmuch as it has been demonstrated that the earliest metabolic deficiencies found in patients with mild cognitive impairments (Minoshima et al. 1997) and during the early stages of Alzheimer's disease are localized to the RSC (Villain et al. 2008). Moreover, during the early stages of Alzheimer's disease RSC atrophy is comparable to that seen in the hippocampus (Pengas et al. 2010). Based on our observations, it is reasonable to suggest that alterations in aRSC functionality may contribute significantly to the typical deficits on recent memory formation and recall observed in early stages of Alzheimer's disease.

The temporal participation of the aRSC in different stages of fear memory processing partially overlaps that of the hippocampus (Izquierdo and Medina 1997; McGaugh 2000). For instance, the role of de novo protein synthesis and gene expression around training in both structures is critical for memory formation and consolidation (Bekinschtein et al. 2007; Alberini 2009), which is in line with correlative studies in humans showing that successful memory formation is associated with an increase in functional connectivity between the hippocampus and some cortical regions, including RSC (Ranganath et al. 2005). The timing of some molecular requirements, however, is different for each structure. For example, while temporary inactivation of the aRSC effectively hampers IA memory retrieval $21 \mathrm{~d}$ after training, pre-test intra-CA1 muscimol impairs IA memory recall up to $14 \mathrm{~d}$ posttraining, but not later (Izquierdo and Medina 1997). These findings are consistent with a recent report in mice and in a different fear-motivated memory task (Corcoran et al. 2011) and with a meta-analysis of functional MRI studies in humans, showing that the RSC is, indeed, very active during retrieval of recent and remote autobiographical memories (Svoboda et al. 2006). In conclusion, the RSC plays an important role in memory processing as a fast learning system that consolidates fear-motivated information and is involved in expression early and also late after acquisition.

\section{Acknowledgments}

We thank Pedro Bekinschtein and Lionel Muller Igaz for their support. This work was supported by grants from the National Agency of Scientific and Technological Promotion and the University of Buenos Aires, Argentina (to J.H.M.) and the National Research Council of Brazil (to M.C.).

\section{References}

Alberini CM. 2008. The role of protein synthesis during the labile phases of memory: Revisiting the skepticism. Neurobiol Learn Mem 89: 234-246.

Alberini CM. 2009. Transcription factors in long-term memory and synaptic plasticity. Physiol Rev 89: 121-145.

Bekinschtein P, Cammarota M, Muller Igaz L, Bevilaqua LRM, Izquierdo I, Medina JH. 2007. Persistence of long-term memory storage requires a late protein synthesis- and BDNF-dependent phase in the hippocampus. Neuron 53: 261-277.

Bourtchouladze R, Abel T, Berman N, Gordon R, Lapidus K, Kandel ER. 1998. Different training procedures recruit either one or two critical periods for contextual memory consolidation, each of which requires protein synthesis and PKA. Learn Mem 5: 365-374.

Cooper BC, Mizumori SJ. 2001. Temporary inactivation of the retrosplenial cortex causes a transient reorganization of spatial coding in the hippocampus. J Neurosci 21: 3986-4001.

Corcoran K, Donnan MD, Tronson NC, Guzman YF, Cao G, Jovasevic V, Guedea AL, Radulovic J. 2011. NMDA receptors in retrosplenial are necessary for recent and remote context fear memory. J Neurosci 31: $11655-11659$.

Daselaar SM, Fleck MS, Dobbins IG, Madden DJ, Cabeza R. 2006. Effects of healthy aging on hippocampal and rhinal memory functions: An event-related fMRI study. Cereb Cortex 16: 1771-1782.

Dudai Y. 2002. Molecular bases of long-term memories: A question of persistence. Curr Opin Neurobiol 12: 211-216.

Dudai Y, Eisenberg M. 2004. Rites of passage of the engram: Reconsolidation and the lingering consolidation hypothesis. Neuron 44: $93-100$.

Dumont JR, Petrides M, Sziklas V. 2010. Fornix and retrosplenial contribution to a hippocampo-thalamic circuit underlying conditional learning. Behav Brain Res 209: 13-20.

Duvarci S, Nader K, LeDoux JE. 2008. De novo mRNA synthesis is required for both consolidation and reconsolidation of fear memories in the amygdala. Learn Mem 15: 747-755.

Frankland PW, Bontempi B. 2005. The organization of recent and remote memories. Nat Rev Neurosci 6: 119-130.

Frankland PW, Bontempi B, Talton LE, Kaczmarek L, Silva AJ. 2004. The involvement of anterior cingulate cortex in remote contextual fear memory. Science 304: $881-883$.

Haijima A, Ichitani Y. 2012. Dissociable anterograde amnesic effects of retrosplenial cortex and hippocampal lesions on spontaneous object recognition memory in rats. Hippocampus 22: 1868-1875.

Harker KT, Whishaw IQ. 2004. Impaired place navigation in place and matching-to-place swimming pool tasks follows both retrosplenial cortex lesions and cingulum bundle lesions in rats. Hippocampus 14: $224-231$. 
Igaz LM, Vianna MR, Medina JH, Izquierdo I. 2002. Two time periods of hippocampal mRNA synthesis are required for memory consolidation of fear-motivated learning. J Neurosci 22: 6781-6789.

Izquierdo I, Medina JH. 1997. Memory formation: The sequence of biochemical events in the hippocampus and its connection to activity in other brain structures. Neurobiol Learn Mem 68: 285-316.

Izquierdo I, Medina JH. 1998. On brain lesions, the milkman and Sigmunda. Trends Neurosci 21: 423-426.

Kandel ER. 2001. The molecular biology of memory storage: A dialogue between genes and synapses. Science 294: 1030-1038.

Keene CS, Bucci DJ. 2008a. Contributions of the retrosplenial and posterior parietal cortices to cue-specific and contextual fear conditioning. Behav Neurosci 122: 89-97.

Keene CS, Bucci DJ. 2008b. Involvement of the retrosplenial cortex in processing multiple conditioned stimuli. Behav Neurosci 122: 651-658.

Keene CS, Bucci DJ. 2008c. Neurotoxic lesions of retrosplenial cortex disrupt signaled and unsignaled contextual fear conditioning. Behav Neurosci 122: 1070-1077.

Lesburgueres E, Gobbo OL, Alaux-Cantin S, Hambuchen A, Trifilieff P, Bontempi B. 2011. Early tagging of cortical networks is required for the formation of enduring associative memory. Science 331: 924-928.

Lima RH, Rossato JI, Furini CR, Bevilaqua LR, Izquierdo I, Cammarota M. 2009. Infusion of protein synthesis inhibitors in the entorhinal cortex blocks consolidation but not reconsolidation of object recognition memory. Neurobiol Learn Mem 91: 466-472.

Martin JH. 1991. Autoradiographic estimation of the extent of reversible inactivation produced by microinjection of lidocaine and muscimol in the rat. Neurosci Lett 127: 160-164.

Maviel T, Durkin TP, Menzaghi F, Bontempi B. 2004. Sites of neocortical reorganization critical for remote spatial memory. Science 305: 96-99.

McGaugh JL. 2000. Memory-a century of consolidation. Science 287: $248-251$.

Minoshima S, Giordani B, Berent S, Frey KA, Foster NL, Kuhl DE. 1997. Metabolic reduction in the posterior cingulate cortex in very early Alzheimer's disease. Ann Neurol 42: 85-94.

Morris RG. 2006. Elements of a neurobiological theory of hippocampal function: The role of synaptic plasticity, synaptic tagging and schemas. Eur J Neurosci 23: 2829-2846.

Paxinos G, Watson C. 1997. The rat brain in stereotaxic coordinates, compact, Vol. 1, 3rd ed. Elsevier Academic Press, Amsterdam.

Pengas G, Hodges JR, Watson P, Nestor PJ. 2010. Focal posterior cingulate atrophy in incipient Alzheimer's disease. Neurobiol Aging 31: 25-33.

Ranganath C, Ritchey M. 2012. Two cortical systems for memory-guided behaviour. Nat Rev Neurosci 13: 713-726.
Ranganath C, Heller A, Cohen MX, Brozinsky CJ, Rissman J. 2005. Functional connectivity with the hippocampus during successful memory formation. Hippocampus 15: 997-1005.

Robinson S, Poorman CE, Marder TJ, Bucci DJ. 2012. Identification of functional circuitry between retrosplenial and postrhinal cortices during fear conditioning. J Neurosci 32: 12076-12086.

Shan Q, Chan GC, Storm D. 2008. Type 1 adenylyl cyclase is essential for maintenance of remote contextual fear memory. J Neurosci 28: 12864-12867.

Squire L. 1992. Memory and the hippocampus: A synthesis of findings with rats, monkeys and humans. Psychol Rev 99: 195-231.

Sutherland RJ, Whishaw IQ, Kolb B. 1988. Contributions of cingulate cortex to two forms of spatial learning and memory. J Neurosci 8: 1863-1872.

Svoboda E, McKinnon MC, Levine B. 2006. The functional neuroanatomy of autobiographical memory: A meta-analysis. Neuropsychologia 44: 2189-2208.

Taubenfeld SM, Wiig KA, Bear MF, Alberini CM. 1999. A molecular correlate of memory and amnesia in the hippocampus. Nat Neurosci 2: 309-310.

Tse D, Langston RF, Kakeyama M, Bethus I, Spooner PA, Morris RGM. 2007. Schemas and memory consolidation. Science 316: 76-82.

Tse D, Takeuchi T, Kakeyama M, Kajii Y, Okuno H, Tohyama C, Bito H, Morris RGM. 2011. Schema-dependent gene activation and memory encoding in neocortex. Science 333: 891-895.

Valenstein E, Bowers D, Verfaellie M, Heilman KM, Day A, Watson RT. 1987. Retrosplenial amnesia. Brain 110: $1631-1646$.

Vann SD, Aggleton JP. 2002. Extensive cytotoxic lesions of the rat retrosplenial cortex reveal consistent deficits on tasks that tax allocentric spatial memory. Behav Neurosci 116: 85-94.

Vann SD, Aggleton JP. 2004. Testing the importance of the retrosplenial guidance system: Effect of different sized retrosplenial cortex lesions on heading direction and spatial working memory. Behav Brain Res 155: 97-108.

Vann SD, Aggleton JP, Maguire EA. 2009. What does the retrosplenial cortex do? Nat Rev Neurosci 10: 792-802.

Villain N, Desgranges B, Viader F, De la Sayette V, Mezengue F, Landeau B, Baron JC, Eutache F, Chetelat G. 2008. Relationships between hippocampal atrophy, white matter disruption, and gray matter hypometabolism in Alzheimer's disease. J Neurosci 28: 6174-6181.

Vogt BA, Peters A. 1981. Form and distribution of neurons in rat cingulate cortex: Areas 32, 24 and 29. J Comp Neurol 195: 603-625.

Received December 18, 2012; accepted in revised form January 10, 2013. 


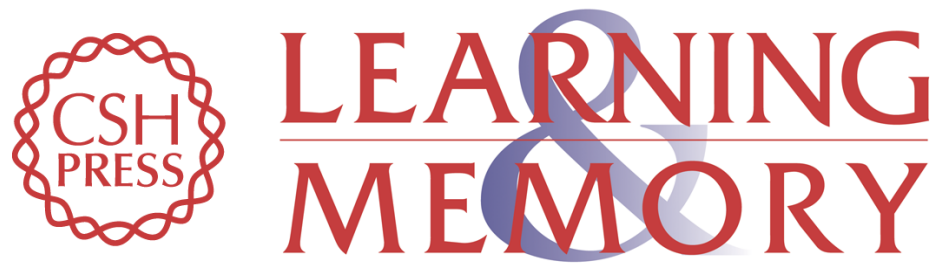

\section{Functional integrity of the retrosplenial cortex is essential for rapid consolidation and recall of fear memory}

Cynthia Katche, Guido Dorman, Leandro Slipczuk, et al.

Learn. Mem. 2013, 20:

Access the most recent version at doi:10.1101/Im.030080.112

Supplemental http://learnmem.cshlp.org/content/suppl/2013/03/13/20.4.170.DC1
Material

References This article cites 46 articles, 16 of which can be accessed free at:

http://learnmem.cshlp.org/content/20/4/170.full.html\#ref-list-1

License

Email Alerting Receive free email alerts when new articles cite this article - sign up in the box at the Service top right corner of the article or click here. 